\title{
Vibrio scophthalmi sp. nov., a New Species from Turbot (Scophthalmus maximus)
}

\author{
MARTA CERDÀ-CUÉLLAR, ${ }^{1 *}$ RAMON A. ROSSELLÓ-MORA, ${ }^{2}$ JORDI LALUCAT, ${ }^{2}$ \\ JOAN JOFRE, ${ }^{1}$ AND ANICET BLANCH ${ }^{1}$
}

\begin{abstract}
Departament de Microbiologia, Facultat de Biologia, Universitat de Barcelona, 08028 Barcelona ${ }^{1}$ and Laboratori de Microbiologia, Departament de Biologia i Ciències de la Salut, Facultat de Ciències, Universitat de les Illes Balears, and Institut d'Estudis Avançats (CSIC-UIB), 07071 Palma de Mallorca, ${ }^{2}$ Spain
\end{abstract}

\begin{abstract}
Six strains isolated from the intestines of juvenile turbot in a fish hatchery in the north of Spain were found to be phenotypically members of the genus Vibrio. However, the phenotypic traits of these organisms did not place them in any of the currently known Vibrio species. These isolates formed an homogeneous group in which the DNA-DNA similarity values (the differences between the thermal denaturation midpoints of the homologous and heterologous duplexes) with reference strain $A 089^{\mathrm{T}}\left(\mathrm{T}=\right.$ type strain) ranged from 0 to $1.7^{\circ} \mathrm{C}$. The results of a 16S rRNA sequence analysis of $\mathrm{A089}^{\mathrm{T}}$ placed this strain in the genus Vibrio in the gamma subclass of the Proteobacteria. The closest relative is Vibrio aestuarianus, with a sequence similarity of $97.8 \%$. This group of strains can be easily differentiated from the other Vibrio species by their clear phenotype. We propose the name Vibrio scophthalmi sp. nov. for these strains; the type strain is strain A089 (= CECT 4638).
\end{abstract}

The genus Vibrio comprises more than 35 species, most of which are widely distributed in marine environments. Some of the members of the genus are pathogenic for humans and marine animals; the pathogenicity is particularly severe if the hosts are under stressed conditions (11). However, members of the genus Vibrio are the most common bacteria in the gastrointestinal flora of many fish $(7,21,22)$. Turbot (Scophthalmus maximus) is a flatfish that is important in aquaculture. High rates of mortality of turbot larvae have been reported during the first days of feeding (36), and these high rates coincide with high levels of a heterogeneous microflora in the gastrointestinal tracts of the larvae. However, when a homogeneous microflora is established in the gut, the fish show enhanced resistance to colonization by bacterial pathogens. The gut microflora may play an important role in preventing colonization by bacterial pathogens $(8,20)$.

A number of phenotypically similar strains were isolated as the dominant bacteria in the gastrointestinal tracts of juvenile turbot ( $S$. maximus) which were reared in a fish hatchery in the north of Spain. These bacteria belong to genus Vibrio on the basis of their phenotypic characteristics. However, these strains could not be identified as members of any of the previously described Vibrio species $(6,11,23,24,34)$. In this study we demonstrate that this group of bacteria constitutes a genotypically well-defined new Vibrio species with a phenotype that is clearly distinct. The name Vibrio scophthalmi is proposed for the new species.

\section{MATERIALS AND METHODS}

Bacterial strains. The six $V$. scophthalmi strains studied (strains $\mathrm{A} 089^{\mathrm{T}}[\mathrm{T}=$ type strain], A102, A105, A107, A110, and SL/G2) were isolated from the gastrointestinal tracts of 35- to 40-day-old turbot. The fish were anesthesized with $10 \mathrm{mg}$ of MS222 (tricaine methane sulfonate) per liter, and after surface disinfection with a $0.1 \%$ benzalkonium chloride saline solution and thorough rinsing with sterile marine phosphate-buffered saline (PBS) $(20 \mathrm{~g}$ of NaCl per liter, $0.2 \mathrm{~g}$ of $\mathrm{KCl}$ per liter, $1.15 \mathrm{~g}$ of $\mathrm{PO}_{4} \mathrm{HNa}_{2}$ per liter, $0.2 \mathrm{~g}$ of $\mathrm{PO}_{4} \mathrm{H}_{2} \mathrm{~K}$ per liter; $\mathrm{pH} 7.1$ to 7.2), the intestine was completely removed from each fish and both the intestine and its contents were homogenized in $10 \mathrm{ml}$ of sterile marine PBS.

${ }^{*}$ Corresponding author. Mailing address: Departament de Microbiologia, Universitat de Barcelona, Diagonal 645, 08028-Barcelona, Spain. Phone: 343402 1489. Fax: 343411 0592. E-mail: cerda@porthos bio.ub.es.
Serial 10-fold dilutions of the homogenate were plated onto tryptone soy agar supplemented with $1.5 \% \mathrm{NaCl}$. The plates were incubated at $20^{\circ} \mathrm{C}$ for $48 \mathrm{~h}$. For reference purposes, the following three strains of different Vibrio species were used in the genotypic characterization: Vibrio aestuarianus LMG $7909^{\mathrm{T}}$, Vibrio mediterranei LMG $11258^{\mathrm{T}}$, and Vibrio splendidus ATCC $33125^{\mathrm{T}}$.

Biochemical characterization. Biochemical characterization was performed by using standard methods. The oxidation-fermentation test and the motility test were performed in Hugh and Leifson's oxidation-fermentation basal medium. The oxidase test, decarboxylase tests, and starch hydrolysis tests were performed as described by Furniss et al. (13). Catalase activity was tested by flooding a nutrient agar plate with $\mathrm{H}_{2} \mathrm{O}_{2}(10 \%)$. Luminiscence was visualized in the dark by using an overnight culture grown on marine agar (Pronadisa) after $10 \mathrm{~min}$ of adaptation to the dark. Sensitivity to vibriostatic agent O/129 (2,4-diamino-6,7diisopropylpteridine) (10 and $150 \mu \mathrm{g}$ ) was determined by using Oxoid discs as recommended by the manufacturer. DNase activity was detected by flooding an 18-h culture grown on DNase agar with $1 \mathrm{~N} \mathrm{HCl}$. Citrate utilization was determined on Simmons citrate agar (Oxoid) as described by Smibert and Krieg (29). Urease activity was tested on Christensen urea agar (Oxoid) as described by Smibert and Krieg (29). The $o$-nitrophenyl- $\beta$-D-galactopyranoside test was performed with Difco discs and marine PBS. Salt tolerance tests were performed on Bacto Peptone (Difco) medium supplemented with $\mathrm{NaCl}(0,0.5,1,2,3,6,8$, $10 \%$ ). Growth in peptone water at different temperatures was tested at $4,22,30$, 37 , and $40^{\circ} \mathrm{C}$. Growth on thiosulfate-citrate-bile salts-sucrose agar $(9,15)$ and VAM (3) was also tested. The test preparations were incubated at $23^{\circ} \mathrm{C}$ and were examined after $24 \mathrm{~h}$. Some test preparations were examined again after $48 \mathrm{~h}$. All of the test media were supplemented with $1.5 \% \mathrm{NaCl}$. In addition, API $20 \mathrm{E}$ strips (BioMérieux SA, Marcy, l'Étoile, France) and Biolog microplate tests (Biolog, Inc., Hayward, Calif.) were used. Both test kits were inoculated and incubated by using the modifications described by Austin et al. (4). A similarity matrix for previously described vibrios $(1,2)$ and the software Bacterial Identifier (T. N. Bryant, Blackwell Scientific Publications, Oxford, United Kingdom) were used to identify the isolates.

DNA isolation and 16S rRNA sequencing. The bacterial strains were grown in $500 \mathrm{ml}$ of marine broth (Difco) for $24 \mathrm{~h}$ at $23^{\circ} \mathrm{C}$. Bacteria were harvested by centrifugation and washed twice in marine PBS. Cells were lysed and DNAs were isolated by the method of Marmur (18). In vitro amplification of 16S rRNA genes and direct sequencing of the amplified DNA fragments were performed as previously described (30).

Sequence data analysis. The sequence determined in this study was added to an alignment of about 3,000 homologous bacterial $16 \mathrm{~S}$ rRNA primary structures by using the aligning tool of the ARB program package (30a). Similarity and distance matrices were calculated with the program ARB-PHYL of the same package. Phylogenetic trees were constructed by using subsets of data that included representative sequences of Vibrio spp. strains (17). We used distance matrix, bootstrapped distance matrix, and maximum-likelihood methods as implemented in the programs of the PHYLIP (12), ARB, and fastDNAml (17) program packages, respectively.

Determination of $\mathbf{G}+\mathbf{C}$ content. The guanine-plus-cytosine $(\mathrm{G}+\mathrm{C})$ content was determined by hydrolyzing the DNA enzymatically and quantifying the nucleosides by high-performance liquid chromatography (31) with the modifications described previously (26). DNA from Escherichia coli B (G+C content, 52 
TABLE 1. Phenotypic properties of $V$. scophthalmi strains ${ }^{a}$

\begin{tabular}{lcl}
\hline \multicolumn{1}{c}{ Test } & $\begin{array}{c}\text { Reaction of } \\
\text { strain } \mathrm{A} 089^{\mathrm{T}}\end{array}$ & \multicolumn{1}{c}{$\begin{array}{c}\text { Strain(s) that give } \\
\text { different results }\end{array}$} \\
\hline L-Alanine & - & SL/G2 \\
Glycogen & - & $\mathrm{A} 107, \mathrm{~A} 110, \mathrm{SL} / \mathrm{G} 2$ \\
D-Trehalose & - & $\mathrm{A} 102, \mathrm{SL} / \mathrm{G} 2$ \\
Turanose & - & $\mathrm{A} 107, \mathrm{SL} / \mathrm{G} 2$ \\
D-Glucuronic acid & - & $\mathrm{A} 102, \mathrm{~A} 110, \mathrm{SL} / \mathrm{G} 2$ \\
Succinamic acid & - & $\mathrm{A} 110, \mathrm{SL} / \mathrm{G} 2$ \\
Glucuronamide & - & $\mathrm{A} 110, \mathrm{SL} / \mathrm{G} 2$ \\
L-Alanylglycine & - & $\mathrm{A} 110, \mathrm{SL} / \mathrm{G} 2$ \\
L-Aspartic acid & - & $\mathrm{A} 110, \mathrm{SL} / \mathrm{G} 2$ \\
Glycyl-L-aspartic acid & - & $\mathrm{A} 110, \mathrm{SL} / \mathrm{G} 2$ \\
Glycyl-L-glutamic acid & - & $\mathrm{A} 110, \mathrm{SL} / \mathrm{G} 2$ \\
\hline
\end{tabular}

${ }^{a}$ Tests that were positive for all of the strains were the tests for motility, oxidase, catalase, $\mathrm{NO}_{2}$ production, arginine dihydrolase, and utilization of $\alpha-\mathrm{D}$ glucose, sucrose, D-fructose, $N$-acetyl-D-glucosamine, and inosine. Tests that were negative for all of the strains were the tests for luminescence, lysine decarboxylase, ornithine decarboxylase, $\mathrm{H}_{2} \mathrm{~S}$ production, urease, gelatinase, amylase, DNase, $\beta$-galactosidase, tryptophan deaminase, indole production, the Voges-Proskauer reaction, and utilization of $\alpha$-cyclodextrin, Tween 80 , citrate, adonitol, D-arabitol, i-erythritol, $m$-inositol, xylitol, D-raffinose, L-rhamnose, Dgalactose, gentibiose, $\alpha$-lactose, $\alpha$-D-lactose, lactulose, D-melibiose, D-sorbitol, D-mannitol, $\beta$-methyl-D-glucoside, formic acid, D-galactonic acid lactone, D-glucosaminic acid, $\alpha$-hydroxybutyric acid, $\gamma$-hydroxybutyric acid, $p$-hydroxyphenylacetic acid, itaconic acid, $\alpha$-ketovaleric acid, malonic acid, quinic acid, D-saccharic acid, sebacic acid, urocanic acid, D-alanine, L-histidine, hydroxy-L-proline, Lphenylalanine, L-pyroglutamic acid, D-serine; DL-carnitine, phenylethylamine, 2-amino-ethanol, glycerol, putrescine, and glucose 1-phosphate.

mol\%) and lambda DNA (G+C content, 49.9 mol\%; Sigma Chemical Co., St. Louis, Mo.) were used as standards.

DNA-DNA hybridization. Purified DNAs of $V$. scophthalmi $\mathrm{A} 089^{\mathrm{T}}$ and $V$. aes tuarianus LMG $7909^{\mathrm{T}}$ were labeled with ${ }^{125} \mathrm{I}$ by the method described by Selin et al. (28). The quantitative bacterial dot method (33) was used in the DNA-DNA hybridization experiment. The hybridization temperature was $25^{\circ} \mathrm{C}$ below the thermal denaturation midpoint $\left(T_{m}\right)$ of the reference strain. DNA-DNA similarity was determined as the difference between the $T_{m}$ of the homologous duplex and the $T_{m}$ of the heterologous duplex $\left(\Delta T_{m}\right)$. The pooled standard deviation in this experiment was $0.43^{\circ} \mathrm{C}$

Nucleotide sequence accession number. The $16 \mathrm{~S}$ rRNA gene sequence determined in this study has been deposited in the GenBank database under accession number U46579.

\section{RESULTS AND DISCUSSION}

Phenotypic characterization. The six strains isolated from turbot have all of the properties of the genus Vibrio; they are facultatively anaerobic short rods that are Gram stain negative and oxidase positive, are susceptible to vibriostatic compound $\mathrm{O} / 129$, and are able to reduce nitrates to nitrites. All of these strains require $\mathrm{NaCl}$, and the optimal range of $\mathrm{NaCl}$ concentrations is 1 to $3 \%$ (wt/vol). None of the six strains grew in alkaline peptone water containing no $\mathrm{NaCl}$, and none grew in the presence of an $\mathrm{NaCl}$ concentration of $6 \%(\mathrm{wt} / \mathrm{vol})$ or more. All of the strains grow well at 22 and $30^{\circ} \mathrm{C}$.

A total of 97 phenotypic features were investigated for the six isolates. This group of organisms was phenotypically homogeneous, and there were only 11 variable traits (Table 1 ). The biochemical properties of the six strains studied did not correspond to those of any previously described Vibrio species $(6,11$, $23,24,25,34)$, as determined by the methods used for identification $(1,2)$. The whole group could be easily differentiated from $V$. aestuarianus and other close relatives by its clearly distinct phenotype (Table 2).

Phylogenetic affiliation. The phylogenetic position of strain A089 ${ }^{\mathrm{T}}$ was investigated by analyzing the $16 \mathrm{~S}$ rRNA gene sequence. The results of this analysis showed that the closest relative of $\mathrm{A} 089^{\mathrm{T}}$ is $V$. aestuarianus $(27,32)$ (sequence similarity, $97.8 \%$ ) (Table 3). A089 $9^{\mathrm{T}}$ is a member of the gamma subclass of the Proteobacteria, and as shown in Fig. 1, A089 appeared to be affiliated with the true vibrios $(10,16)$ together with the marine vibrios (5). In all cluster analyses a common root with $V$. aestuarianus was observed, and the new organisms formed an isolated branch within the vibrio cluster. In any case, both $\mathrm{A} 089^{\mathrm{T}}$ and $V$. aestuarianus appeared to be on the same phylogenetic branch as Vibrio metschnikovii, as was observed when partial sequences were used (14). The sequence signatures for the genus described by Dorsch et al. (10) were also conserved in $\mathrm{A} 089^{\mathrm{T}}$. The $16 \mathrm{~S}$ rRNA similarity to the closest relative, $V$. aestuarianus, is the same as the mean of the similarities among the 13 species included on branch B1 (Fig. 1). Some of the species on this branch have nearly identical se-

TABLE 2. Characteristics that are useful for distinguishing $V$. scophthalmi from its closest relatives ${ }^{a}$

\begin{tabular}{|c|c|c|c|c|c|c|}
\hline Test & V. scophthalmi & $V$. aestuarianus & V. splendidus I & V. splendidus $I I$ & V. vulnificus & V. mediterranei \\
\hline Arginine dihydrolase & $t^{b}$ & + & $(+)$ & $\mathrm{v}$ & - & - \\
\hline Lysine decarboxylase & - & $\mathrm{v}$ & - & - & + & + \\
\hline Ornithine decarboxylase & - & - & - & - & + & - \\
\hline Indole & - & + & + & d & + & + \\
\hline $\mathrm{ONPG}^{c}$ & - & $+^{d}$ & $(+)$ & $\mathrm{v}$ & + & $+^{d}$ \\
\hline Citrate & - & + & + & + & + & - \\
\hline D-Glucosamine & + & $--^{d}$ & - & - & + & $+^{d}$ \\
\hline \multicolumn{7}{|l|}{ Utilization of: } \\
\hline Sucrose & + & + & $(+)$ & - & $(-)$ & + \\
\hline D-Mannitol & - & + & + & + & $(+)$ & + \\
\hline \multicolumn{7}{|l|}{ Production of: } \\
\hline Gelatinase & - & + & + & + & + & - \\
\hline Amylase & - & $+^{d}$ & + & + & + & $\mathrm{v}$ \\
\hline Growth in the presence of $6 \% \mathrm{NaCl}$ & - & + & + & $\mathrm{v}$ & $\mathrm{d}$ & + \\
\hline \multicolumn{7}{|l|}{ Growth at: } \\
\hline $4^{\circ} \mathrm{C}$ & - & + & d & - & - & - \\
\hline $35^{\circ} \mathrm{C}$ & + & + & $\mathrm{v}$ & - & + & $(+)$ \\
\hline $40^{\circ} \mathrm{C}$ & - & - & - & - & + & - \\
\hline
\end{tabular}

${ }^{a}$ The data for taxa other than $V$. scophthalmi were obtained from references $1,2,6,11$, and 25 .

${ }^{b}+$, more than $90 \%$ of the strains are positive; $(+), 75$ to $89 \%$ of the strains are positive; $v, 26$ to $74 \%$ of the strains are positive; $(-), 11$ to $25 \%$ of the strains are positive; - less than $10 \%$ of the strains are positive; $\mathrm{d}$, values determined in previous studies differ.

${ }^{c}$ ONPG, $o$-nitrophenyl- $\beta$-D-galactopyranoside.

${ }^{d}$ Result obtained for the type strain. 
TABLE 3. Genotypic characteristics of strains of V. scophthalmi and closely related Vibrio species

\begin{tabular}{|c|c|c|c|c|c|c|}
\hline \multirow{2}{*}{ Species } & \multirow{2}{*}{ Strain $^{a}$} & \multicolumn{2}{|c|}{$\Delta T_{m}\left({ }^{\circ} \mathrm{C}\right)$ with: } & \multicolumn{2}{|c|}{$\begin{array}{l}\% \text { 16S rRNA sequence } \\
\text { similarity with: }\end{array}$} & \multirow{2}{*}{$\begin{array}{c}\mathrm{G}+\mathrm{C} \text { content } \\
(\mathrm{mol} \%)\end{array}$} \\
\hline & & $\mathrm{A} 089^{\mathrm{T}}$ & V. aestuarianus & $\mathrm{A} 089^{\mathrm{T}}$ & V. aestuarianus & \\
\hline V. aestuarianus & LMG $7909^{\mathrm{T}}$ & 7.1 & 0 & 97.8 & & $43-44^{b}$ \\
\hline$V$. mediterranei & LMG $11258^{\mathrm{T}}$ & 8.5 & 6 & 96.3 & 96.9 & $42-43^{c}$ \\
\hline V. splendidus & $\operatorname{ATCC} 33125^{\mathrm{T}}$ & 10.2 & 7.4 & 96.2 & 97.0 & $45-46^{d}$ \\
\hline \multirow{6}{*}{ V. scophthalmi } & $\mathrm{A} 089^{\mathrm{T}}$ & 0 & 6.8 & & 97.8 & 45.3 \\
\hline & A102 & 0 & 7.7 & & & 44.7 \\
\hline & A105 & 1.7 & & & & 43.8 \\
\hline & A107 & 1.1 & & & & 44.4 \\
\hline & A110 & 0.8 & & & & 44.0 \\
\hline & $\mathrm{SL} / \mathrm{G} 2$ & 0.7 & & & & 45.5 \\
\hline
\end{tabular}

\footnotetext{
a ATCC, American Type Culture Collection, Rockville, Md.; LMG, Laboratorium voor Microbiologie, Rijksuniversiteit, Ghent, Belgium.

${ }^{b}$ Data from reference 32 .

${ }^{c}$ Data from reference 25 .

${ }^{d}$ Data from reference 6.
}

quences, although genomically they are clearly separate species (19).

G $+\mathrm{C}$ content and DNA-DNA hybridization. The $\mathrm{G}+\mathrm{C}$ contents of the isolates ranged from 44 to $45.5 \mathrm{~mol} \%$ (Table 3 ), which was consistent with the overall values for the genus (16). These $\mathrm{G}+\mathrm{C}$ contents are similar to the value observed for $V$. aestuarianus (32). DNA-DNA hybridization studies were performed with all of the isolates and representative Vibrio species. All of the new isolates were closely related to each other, and the $\Delta T_{m}$ with reference strain $A 089^{\mathrm{T}}$ was never higher than $1.7^{\circ} \mathrm{C}$. However, this group of strains was genomically distant $\left(\Delta T_{m}, 6.8\right.$ to $\left.7.1^{\circ} \mathrm{C}\right)$ from the phylogenetically closest known species, $V$. aestuarianus (Table 3 ).

The six new isolates constitute a new species within the genus Vibrio, as shown by the overall results. The differences in $\Delta T_{m}$ between the new isolates and the phylogenetically closest species, together with the distinct phenotypic profile of the new isolates, indicate that the new strains are members of a new Vibrio species (35). We propose the name Vibrio scophthalmi sp. nov. for this group of strains.

Description of Vibrio scophthalmi sp. nov. Vibrio scophthalmi (scoph. thal' mi. L. gen. n. scophthalmi, of turbot [Scophthalmus maximus]). Gram-negative, motile, short rods. Colonies

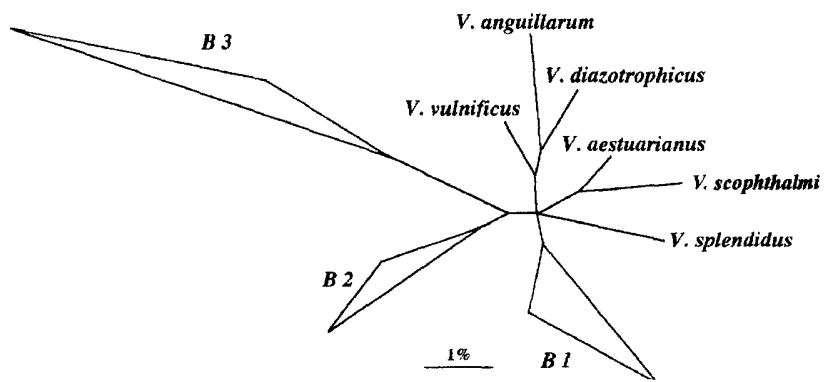

FIG. 1. 16S rRNA-based tree reflecting the phylogenetic relationships of V. scophthalmi $\mathrm{A} 089^{\mathrm{T}}$ and a selection of available type strains of members of the genus Vibrio. The tree is based on the results of a distance matrix analysis of complete or almost complete $16 \mathrm{~S}$ rRNA sequences. The common root of $\mathrm{A} 089^{\mathrm{T}}$ and $V$. aestuarianus and their isolated position within the genus were not different in trees calculated with other methods. Branch 1 (B1) includes $V$. carchariae, $V$. campbellii, $V$. haveyi, $V$. alginolyticus, $V$. parahaemolyticus, $V$. natriegens, $V$. pe lagius, $V$ proteolyticus, $V$ nereis, $V$ tubiashi, $V$. orientalis, $V$. mediterranei, and $V$. fluvialis (mean similarity level, $97.8 \%$ ); branch 2 (B2) comprises $V$. cincinnatiensis, $V$. metschnikovii, and $V$. gazogenes (mean similarity level, 95.7\%); and branch 3 (B3) includes $V$. damsela, $V$. costicola, and $V$. hollisae (mean similarity level, $92.4 \%$ ). are regular and unpigmented. Does not swarm. Grows on thiosulfate-citrate-bile salts-sucrose agar, producing yellow colonies, and does not grow on VAM. Both oxidative metabolism and fermentative metabolism occur. Oxidase and catalase tests are positive. Reduces nitrate to nitrite. Sensitive to vibriostatic agent $\mathrm{O} / 129$ (10 or $150 \mu \mathrm{g}$ per disc) and does not produce gas from glucose. $V$. scophthalmi cannot grow at 4,37 , or $40^{\circ} \mathrm{C}$, but grows well at 22 and $30^{\circ} \mathrm{C}$. It grows weakly in culture media supplemented with $0.5 \%$ (wt/vol) $\mathrm{NaCl}$ and does not grow when $\mathrm{NaCl}$ is absent. The optimal $\mathrm{NaCl}$ concentration for growth is 1 to $3 \%$ (wt/vol), and it does not grow at higher $\mathrm{NaCl}$ concentrations $(6,8,10 \%)$. Additional properties are showed in Tables 1 and 2.V. scophthalmi has a $\mathrm{G}+\mathrm{C}$ content of 44 to $45.5 \mathrm{~mol} \%$.

Description of the type strain. Strain A089 is the type strain of $V$. scophthalmi. It has biochemical and molecular characteristics described above. The $\mathrm{G}+\mathrm{C}$ content of its DNA is 45.3 mol\%, and it has a $T_{m}$ of $69.7^{\circ} \mathrm{C}$ in $0.1 \times \mathrm{SSC}(1 \times \mathrm{SSC}$ is 0.15 $\mathrm{M} \mathrm{NaCl}$ plus $0.015 \mathrm{M}$ sodium citrate). Strain A089 ${ }^{\mathrm{T}}$ has been deposited in the Colección Española de Cultivos Tipo, València, Spain, as strain CECT $4638^{\mathrm{T}}$.

\section{ACKNOWLEDGMENTS}

Financial support was provided by European Union contract AIR CT94-1601 and in part by CICYT (Spain) project AMB94-0760.

\section{REFERENCES}

1. Alsina, M., and A. R. Blanch. 1994. A set of keys for biochemical identification of environmental Vibrio species. J. Appl. Bacteriol. 76:79-85.

2. Alsina, M., and A. R. Blanch. 1994. Improvement and update of a set of keys for biochemical identification of Vibrio species. J. Appl. Bacteriol. 77:719721.

3. Alsina, M., J. Martínez-Picado, J. Jofre, and A. R. Blanch. 1994. A medium for presumptive identification of Vibrio anguillarum. Appl. Environ. Microbiol. 60:1681-1683.

4. Austin, B., M. Alsina, D. A. Austin, A. R. Blanch, F. Grimont, P. A. D. Grimont, J. Jofre, S. Koblavi, J. L. Larsen, K. Pedersen, T. Tiainen, L. Verdonck, and J. Swings. 1995. Identification and typing of Vibrio anguillarum: a comparison of different methods. Syst. Appl. Microbiol. 18:285-302.

5. Baumann, P., L. Baumann, S. S. Bang, and M. J. Woolkalis. 1980. Reevaluation of the taxonomy of Vibrio, Beneckea and Photobacterium: abolition of the genus Beneckea. Curr. Microbiol. 4:127-132.

6. Baumann, P., A. L. Furniss, and J. V. Lee. 1984. Genus Vibrio, p. 518-538 In N. R. Krieg and J. G. Holt (ed.), Bergey's manual of systematic bacteriology, vol. 1. The Williams \& Wilkins Co., Baltimore, Md.

7. Berg, O. 1995. Bacteria associated with early life stages of halibut, Hippoglossus hippoglossus L., inhibit growth of a pathogenic Vibrio sp. J. Fish Dis. 18:31-40.

8. Blanch, A. R., M. Simón, J. Jofre, and G. Minkoff. 1991. Bacteria associated with hatchery cultivated turbot: are they implicated in rearing success?, p. 392-394. In Larvi'91-Fish \& Crustacean Larviculture Symposium. Euro- 
pean Aquaculture Society publication 15. European Aquaculture Society, Ghent, Belgium.

9. Bolinches, J., J. L. Romalde, and A. E. Toranzo. 1988. Evaluation of selective media for isolation and enumeration of vibrios from estuarine waters. J. Microbiol. Methods 8:151-160.

10. Dorsch, M., D. Lane, and E. Stackebrandt. 1992. Towards a phylogeny of the genus Vibrio based on 16S rRNA sequences. Int. J. Syst. Bacteriol. 42:58-63.

11. Farmer, J. J., and F. W. Hickman-Brenner. 1992. The genera Vibrio and Photobacterium, p. 2952-3011. In A. Balows, H. G. Trüper, M. Dworkin, W. Harder, and K.-H. Schleifer (ed.), The prokaryotes. A handbook on the biology of bacteria: ecophysiology, isolation, identification, applications, 2nd ed. Springer-Verlag, New York, N.Y.

12. Felsenstein, J. 1982. Numerical methods for inferring phylogenetic trees. Q. Rev. Biol. 57:379-404.

13. Furniss, A. L., J. V. Lee, and T. J. Donovan. 1978. The vibrios. Public Health Laboratory Service Monograph Series no. 11. Public Health Laboratory Service, London, United Kingdom

14. Kita-Tsukamoto, K., H. Oyaizu, K. Nanba, and U. Simidu. 1993. Phylogenetic relationships of marine bacteria, mainly members of the family Vibrionaceae, determined on the basis of $16 \mathrm{~S}$ rRNA sequences. Int. J. Syst. Bacteriol. 43:8-19.

15. Kobayashi, T., S. Enomoto, R. Sakazaki, and S. Kuwahara. 1963. A new selective medium for pathogenic vibrios: TCBS agar (modified Nakanishi's agar). Nippon Saikingaku Zasshi 18:387-391.

16. MacDonell, M. T., and R. R. Colwell. 1985. Phylogeny of the Vibrionaceae, and recommendation for two new genera, Listonella and Shewanella. Syst. App. Microbiol. 6:171-182.

17. Maidak, B. L., N. Larsen, M. J. MacCaughey, R. Overbeek, G. Olsen, K Fogel, J. Blandy, and C. R. Woese. 1994. The Ribosomal Database Project. Nucleic Acids Res. 22:3485-3487.

18. Marmur, J. 1961. A procedure for the isolation of deoxyribonucleic acid from microorganisms. J. Mol. Biol. 3:208-218.

19. Molitoris, E., M. A. Marii, S. W. Joseph, M. I. Krichevsky, G. R. Fanning, G. Last, A. M. El-Mishad, Y. A. El Batawi, and R. R. Colwell. 1989. Numerical taxonomy and deoxyribonucleic acid relatedness of environmental and clinical Vibrio species isolated in Indonesia. Int. J. Syst. Bacteriol. 39:442-449.

20. Munro, P. D., A. Barbour, and T. H. Birkbeck. 1995. Comparison of the growth and survival of larval turbot in the absence of culturable bacteria with those in the presence of Vibrio anguillarum, Vibrio alginolyticus, or a marine Aeromonas sp. Appl. Environ. Microbiol. 61:4425-4428.

21. Muroga, K., M. Higahsi, and J. Keitoku. 1987. The isolation of intestinal microflora of farmed red seabream (Pagrus major) and black seabream (Acanthopagrus schlegeli) at larval and juvenile stages. Aquaculture 65:79-88.

22. Onarheim, A. M., and J. Raa. 1990. Characteristics and possible biological significance of an autochtonous flora in the intestinal mucosa of seawater fish, p. 197-201. In R. Lesel (ed.), Microbiology in poecilotherms. Elsevier Science Publishers, Amsterdam, The Netherlands.

23. Onarheim, A. M., R. Wiik, J. Burghardt, and E. Stackebrandt. 1994. Char- acterization and identification of two Vibrio species indigenous to the intestine of fish in cold sea water; description of Vibrio iliopiscarius sp. nov. Syst. Appl. Microbiol. 17:370-379.

24. Pujalte, M. R., M. Ortigosa, M. C. Urdaci, E. Garay, and P. A. D. Grimont. 1993. Vibrio mytili sp. nov., from mussels. Int. J. Syst. Bacteriol. 43:358-362.

25. Pujalte, M. R., B. A. Ortiz-Conde, S. E. Steven, C. Esteve, E. Garay, and R. R. Colwell. 1992. Numerical taxonomy and nucleic acid studies of Vibrio mediterranei. Syst. Appl. Microbiol. 15:82-91.

26. Rosselló, R., E. Garcia-Valdés, J. Lalucat, and J. Ursing. 1991. Genotypic and phenotypic diversity of Pseudomonas stutzeri. Syst. Appl. Microbiol. 14: 150-157.

27. Ruimy, R., V. Breittmayer, P. Elbaze, B. Lafay, O. Boussemart, M. Gauthier, and R. Christen. 1994. Phylogenetic analysis and assessment of the genera Vibrio, Photobacterium, Aeromonas and Plesiomonas deduced from smallsubunit rRNA sequences. Int. J. Syst. Bacteriol. 44:416-426.

28. Selin, Y. M., B. Harich, and J. L. Johnson. 1983. Preparation of labeled nucleic acids (nick translation and iodination) for DNA homology and rRNA hybridization experiments. Curr. Microbiol. 8:127-132.

29. Smibert, R. M., and N. R. Krieg. 1994. Phenotypic characterization, p. 607-654. In P. Gerhardt, R. G. E. Murray, W. A. Wood, and N. R. Krieg (ed.), Methods for general and molecular bacteriology. ASM Press, Washington, D.C.

30. Springer, N., W. Ludwig, R. Amann, H. J. Schmidt, H. D. Gorth, and K. H. Schleifer. 1993. Occurrence of fragmented 16S rRNA in an obligate bacterial endosymbiont of Paramecium caudatum. Proc. Natl. Acad. Sci. USA 90: 9892-9895.

30a.Strunk, O., and W. Ludwig. Unpublished data.

31. Tamaoka, J., and K. Komagata. 1984. Determination of DNA base composition by reversed-phase high-performance liquid chromatography. FEMS Microbiol. Lett. 25:125-128.

32. Tison, D. L., and R. J. Seidler. 1983. Vibrio aestuarianus: a new species from estuarine waters and shellfish. Int. J. Syst. Bacteriol. 33:699-702.

33. Tjernberg, I., E. Lindh, and J. Ursing. 1989. A quantitative bacterial dot method for DNA-DNA hybridization and its correlation to the hydroxyapatite method. Curr. Microbiol. 18:77-81.

34. Urdaci, M. C., M. Marchand, E. Ageron, J. M. Arcos, B. Sesma, and P. A. D. Grimont. 1991. Vibrio navarrensis sp. nov., a species from sewage. Int. J. Syst. Bacteriol. 41:290-294.

35. Wayne, L. G., D. J. Brenner, R. R. Colwell, P. A. D. Grimont, O. Kandler, M. I. Krichevsky, L. H. Moore, W. E. C. Moore, R. G. E. Murray, E. Stackebrandt, M. P. Starr, and H. G. Trüper. 1987. Report of the Ad Hoc Committee on Reconciliation of Approaches to Bacterial Systematics. Int. J. Syst. Bacteriol. 37:463-464.

36. Westerdahl, J., C. Olsson, P. L. Conway, and S. Kjelleberg. 1994. Characterization of turbot (Scophthalmus maximus) associated bacteria with inhibitory effects against the fish pathogen Vibrio anguillarum. Acta Microbiol. Immunol. Hung. 41:403-409. 